\title{
PREFERENSI BERMUKIM MASYARAKAT PERBATASAN KOTA DAN KABUPATEN MALANG (DESA NGIJO KECAMATAN KARANGPLOSO)
}

\author{
Anisah Azizah ${ }^{1)}$ \\ Turniningtyas Ayu $\mathbf{R}^{2)}$ \\ I Nyoman Suluh Wijaya ${ }^{3)}$ \\ Magister Teknik Sipil, Minat Perencanaan Wilayah dan Kota, Universitas Brawijaya ${ }^{1,2,3)}$ \\ Penulis Korespondensi e-mail : aniizaah12@gmail.com
}

\begin{abstract}
Development of city center encourages development in frontier city. Ngijo Village, one of frontier areas of Malang City and Malang Regency, was identified as expanding urban activity from Malang City which keep increasing from time to time, resulted in the rapid growth of settlements in the area. Increase of settlements in Ngijo village is growing rapidly, it is influenced by housing preference of residents. The method used in research is quantitative research with analytical technique used is the technique of conjoin analysis. Based on result of conjoint analysis, importance value in each attribute / variable is choice of housing unit with the importance value of 38,3\%, environmental factor with importance value of 35,9\%, accessibility with importance value of $14,3 \%$ and the last, choice of infrastructure with importance value of $11.5 \%$. Choice of housing units to be the most dominant choice, while choice of infrastructure to be the lowest choice of living factors due to facilities and infrastructure available in the neighborhood of Ngijo Village is relatively low when compared with the city center.
\end{abstract}

Keywords: housing preference, conjoin analysis

\begin{abstract}
ABSTRAK
Perkembangan pusat kota mendorong terjadinya perkembangan di daerah perbatasan kota. Desa Ngijo salah satu kawasan perbatasan Kota Malang dan Kabupaten Malang, teridentifikasi terkena perluasan kegiatan perkotaan dari Kota Malang yang terus meningkat dari waktu ke waktu, yang mengakibatkan pertumbuhan permukiman yang cukup pesat pada kawasan tersebut. peningkatan permukiman pada Desa Ngijo semakin pesat, hal tersebut tentunya sangat dipengaruhi oleh preferensi bermukim dari masyarakatnya. Metode yang digunakan dapam penelitian merupakan penelitian kuantitatif dengan teknik analisis yang digunakan adalah teknik analisis konjoin. Berdasarkan hasil analisis konjoin nilai kepentingan pada masingmasing atribut/variabel adalah pilihan unit rumah dengan nilai kepentingan 38,3\%, faktor lingkungan dengan nilai kepentingan 35,9\%, aksesibilitas dengan nilai kepentingan $14,3 \%$ dan yang terakhir pilihan infrastruktur dengan nilai kepentingan 11,5\%. Pilihan unit rumah menjadi pilihan yang paling dominan, sedangkan pilihan infrastruktur menjadi faktor pilihan bermukim yang paling rendah dikarenakan sarana dan prasarana yang tersedia di lingkungan permukiman Desa Ngijo tergolong rendah apabila dibandingkan dengan pusat kota. Kata kunci:preferensi bermukim, analisis konjoin
\end{abstract}




\section{PENDAHULUAN}

Peningkatan penggunaan lahan sebagai upaya pemenuhan kebutuhan penduduk seperti hunian, tempat usaha dan fasilitas umum membuat ketersedian lahan semakin berkurang, fenoma ini sering terjadi di kawasan urban fringe (Rupini, 2017). Perkembangan pusat kota mendorong terjadinya perkembangan di daerah pinggiran. Daerah pinggiran kota tersebut merupakan perbatasan kota yang berkembang sebagai dampak tidak terpenuhinya kebutuhan lahan permukiman di daerah pusat kota. Terjadinya perubahan penggunaan lahan di pusat kota mendesak warga kota untuk mencari tempat tinggal di pinggir kota yang mengakibatkan wilayah pinggiran dan perbatasan harus menampung beban pertumbuhan cepat (Sadana, 2014). Akibatnya terjadi perkembangan di kawasan perbatasan, antara lain perkembangan permukiman yang cukup pesat. Desa Ngijo merupakan salah satu kawasan perbatasan Kota Malang dan Kabupaten Malang yang secara admisnistratif berada pada Kecamatan Karangploso. Berdasarkan RTRW Kabupaten Malang Tahun 2007-2027, Desa Ngijo teridentifikasi terkena perluasan kegiatan perkotaan dari Kota Malang yang terus meningkat dari waktu ke waktu, yang mengakibatkan pertumbuhan permukiman yang cukup pesat pada kawasan tersebut.

Proses berkembangnya kawasan batas kota dapat dikaitkan dengan perkembangan suatu kota berupa perkembangan spasial sentrifugal, yaitu suatu proses bertembahnya ruang perkotaan ke arah luar dari kawasan perkotaan, sehingga kawasan perbatasan dapat menjadi area perluasan perkotaan (Oktaviani, etc all, 2016). Proses tersebut akan membawa konsekuensi bertambahnya volume ruang untuk menampung kegiatan dan kebutuhan penduduk (Ekartaji, 2013). Perkembang kawasan perbatasan tidak disertai dengan perkembangan yang memadai di bidang infrastruktur dan sarana-prasarana permukiman perkotaan, serta tidak terencana dengan baik sehingga terjadi beberapa permasalahan. Permasalahan yang terjadi antara lain yaitu fasilitas permukiman tidak merata penyebarannya, sehingga beberapa daerah di kawasan tersebut tidak terlayani dengan baik oleh fasilitas permukiman. Terkait hal tersebut, mengakibatkan masyarakat membutuhkan sarana penunjang (transportasi) untuk mencapai fasilitas yang dibutuhkan. Permasalahan lain yaitu, rendahnya tingkat aksesibilitas apabila dikaitkan dengan sarana transportasi, yaitu minimya sarana transportasi umum yang dapat digunakan sehingga masyarakat secara tidak langsung dituntut untuk memiliki kendaraan pribadi sebagai penunjang mobilitas harian. 
Tidak dapat dipungkiri peningkatan permukiman pada Desa Ngijo semakin pesat, hal tersebut tentunya sangat dipengaruhi oleh preferensi bermukim dari masyarakatnya. Preferensi bermukim adalah keinginan atau kecenderungan seseorang untuk bermukim atau tidak bermukim disuatu tempat (Sinulingga, 2005). Masyarakat pada kawasan tersebut tidak hanya memiliki satu pilihan, namun memiliki pereferensi yang beragam dalam pemilihan lokasi bermukim. Oleh sebab itu, dilakukan penelitian terkait preferensi bermukim pada kawasan perbatasan Kota Malang, tentunya hal tersebut akan dapat menjadi salah satu masukan dalam perencanaan penggunaan lahan, khususnya di daerah pinggiran dan perbatasan kota.

\section{METODOLOGI}

Jenis penelitian terkait preferensi bermukim masyarakat di perbatasan Kota dan Kabupaten Malang merupakan penelitian kuantitatif. Berdasarkan teknik yang digunakan di dalam penelitian dan tingkat kealamian tempat penelitian, jenis metode penelitian merupakan penelitian survei, yaitu penelitian yang tidak melakukan perubahan atau perlakuan khusus terhadap variabel-variabel yang digunakan dalam penelitian (Hasan, 2004). Penelitian survei digunakan untuk mendapatkan data dari tempat tertentu yang alamiah, tetapi peneliti melakukan perlakuan dalam pengumpulan data, misalnya dengan mengedarkan angket, tes, wawancara terstruktur dan sebagainya (Sugiyono, 2011), dalam hal ini pada penelitian terkait preferensi bermukim masyarakat perbatasan Kota Malang dan Kabupaten Malang di Desa Ngijo menggunakan angket dalam proses pengumpulan data.

\section{Teknik Pengumpulan Data}

Berdasarkan sumber data, data yang digunakan pada penelitian terkait preferensi bermukim masyarakat perbatasan Kota Malang pada Desa Ngijo terbagi menjadi dua, yaitu data primer dan data sekunder. Secara umum teknik pengumpulan data yang digunakan dalam penelitian adalah dengan angket, observasi, dan survei sekunder.Populasi dalam penelitian terkait preferensi bermukim masyarakat perbatasan Kota dan Kabupaten Malang adalah seluruh masyarakat pendatang yang memilih bermukim di Desa Ngijo, Kecamatan Karangploso. Unit analisis penelitian terkait preferensi bermukim masyarakat perbatasan Kota Malang dan Kabupaten Malang adalah masyarakat pendatang yang diasumsuikan tiap satu rumah diwakilkan oleh satu orang yaitu kepala keluarga yang bertempat tinggal di wilayah studi (Desa Ngijo). 
Teknik pengambilan sampel yang digunakan adalah non probability sampling. Teknik untuk menentukan jumlah sampel yang digunakan adalah linier time function. Dalam perhitungannya linier time function tidak menggunakan jumlah populasi, namun menggunakan estimasi waktu penelitian, teknik penentuan jumlah sampel berdasarkan estimasi kendala waktu, dan perhitungannya menggunan rumus sebagai berikut:

$\boldsymbol{n}=\frac{T-t_{0}}{t 1}$

Keterangan:

$\mathrm{n} \quad=$ Jumlah sampel terpilih

$\mathrm{T}$ = Waktu yang tersedia untuk penelitian (jam)

$\mathrm{t}_{0}=$ Waktu tetap (jam)

$\mathrm{t}_{1}=$ Waktu yang digunakan untuk sampling unit (jam)

Berdasarkan rumus 4.1, maka dapat dilakukan perhitungan jumlah sampel, yaitu:

$\mathrm{T}=30$ hari $\mathrm{x} 7 \mathrm{jam} / \mathrm{hari}=210 \mathrm{jam}$

$\mathrm{t}_{0}=5 \mathrm{jam} /$ hari $\mathrm{x} 30$ hari $=150 \mathrm{jam}$

$\mathrm{t}_{1}=0,5 \mathrm{jam}$

$n=\frac{T-t_{0}}{t 1}=\frac{210-150}{0,5}=\frac{60}{0,5}=120$ sampel

Berdasarkan hasil perhitungan, jumlah sampel yang akan digunakan dalam penelitian adalah berjumlah 120 sampel.

\section{Variabel Penelitian}

Variabel digunakan untuk mempermudah dalam proses penelitian terkaitpreferensi bermukim masyarakat perbatasan Kota Malang. Berdasarkan teori dan studi terdahulu ditetapkan variabel penelitian, yaitu:

a. Pilihan unit rumah, dengan sub variabel terdiri dari keterjangkauan harga rumah, jaminan kepemilikan, dan tipe rumah.

b. Aksesibilitas, dengan sub variabel terdiri dari ketersediaan moda transportasi dan jarak dengan lokasi kegiatan.

c. Faktor lingkungan, dengan sub variabel terdiri dari kedekatan dengan keluarga, kesehatan, keamanan, dan komunitas.

d. Pilihan infrastruktur, dengan sub variabel terdiri dari ketersediaan fasilitas umum, dan ketersediaan infrastruktur rekreasi 


\section{Teknik Analisis Konjoin}

Analisis konjoin merupakan sebuah pendekatan untuk mengukur pilihan masyarakat terhadap beberapa atribut, yaitu dengan pelaksanaan yang didasarkan pada desain eksperimen (Supranto, 2010). Analisis konjoin merupakan analisis yang dipertimbangkan bersama dan digunakan untuk meneliti dampak atribut benda/jasa secara serempak terhadap preferensi seseorang (Jansenet.al., 2011).Analisis konjoin dipilih dengan pertimbangan bahwa menggunakan analisis ini dapat diketahui lebih spesifik pilihan atau preferensinya karena responden akan menilai (memberikan rating) sendiri terhadap pilihan yang ada sehingga hasil lebih objektif. Analisis konjoin yang digunakan pada penelitian preferensi bermukim masyarakat perbatasan Kota dan Kabupaten Malang (Desa Ngijo Kecamatan Karangploso) ialah full profile conjoint yaitu dengan jumlah atribut (variabel) $\leq 6$. Tahapan analisis dapat dilihat pada Gambar 1 dan stimuli yang terbentuk pada analisis konjoin dapat dilihat pada Tabel 1.

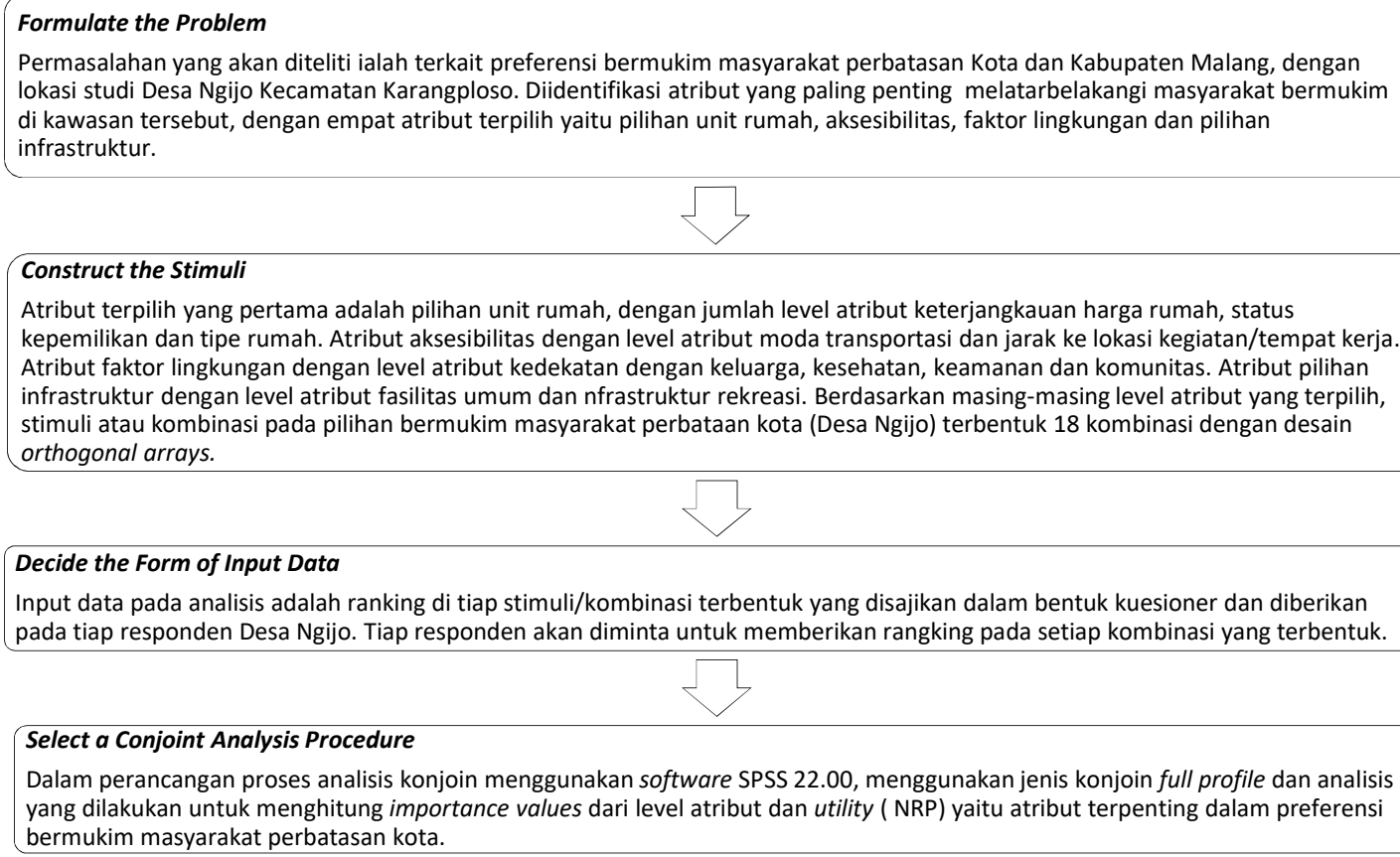

Dalam perancangan proses analisis konjoin menggunakan software SPSS 22.00, menggunakan jenis konjoin full profile dan analisis yang dilakukan untuk menghitung importance values dari level atribut dan utility (NRP) yaitu atribut terpenting dalam preferensi bermukim masyarakat perbatasan kota.

Gambar 1. Tahapan Analisis Konjoin Sumber: Supranto, 2010 
Tabel 1.Stimulti Level Atribut Preferensi Bermukim Masyarakat

\begin{tabular}{|c|c|c|c|c|c|}
\hline & $\begin{array}{l}\text { Card } \\
\text { ID }\end{array}$ & $\begin{array}{l}\text { Pilihan unit } \\
\text { rumah }\end{array}$ & Aksesibilitas & $\begin{array}{c}\text { Faktor } \\
\text { lingkungan }\end{array}$ & $\begin{array}{c}\text { Pilihan } \\
\text { infrastruktur }\end{array}$ \\
\hline 1 & 1 & $\begin{array}{l}\text { Keterjangkauan } \\
\text { harga rumah }\end{array}$ & $\begin{array}{c}\text { Jarak dengan lokasi } \\
\text { kegiatan/tempat kerja }\end{array}$ & $\begin{array}{l}\text { Kedekatan } \\
\text { dengan } \\
\text { keluarga }\end{array}$ & $\begin{array}{c}\text { Ketersediaan } \\
\text { infrastruktur } \\
\text { rekreasi }\end{array}$ \\
\hline 2 & 2 & Status kepemilikan & Moda transportasi & Kesehatan & $\begin{array}{c}\text { Ketersediaan } \\
\text { fasilitas umum }\end{array}$ \\
\hline 3 & 3 & $\begin{array}{l}\text { Keterjangkauan } \\
\text { harga rumah }\end{array}$ & Moda transportasi & Komunitas & $\begin{array}{c}\text { Ketersediaan } \\
\text { infrastruktur } \\
\text { rekreasi }\end{array}$ \\
\hline 4 & 4 & $\begin{array}{l}\text { Keterjangkauan } \\
\text { harga rumah }\end{array}$ & $\begin{array}{c}\text { Jarak dengan lokasi } \\
\text { kegiatan/tempat kerja }\end{array}$ & Kesehatan & $\begin{array}{c}\text { Ketersediaan } \\
\text { infrastruktur } \\
\text { rekreasi }\end{array}$ \\
\hline 5 & 5 & Tipe rumah & Moda transportasi & $\begin{array}{c}\text { Kedekatan } \\
\text { dengan } \\
\text { keluarga }\end{array}$ & $\begin{array}{l}\text { Ketersediaan } \\
\text { fasilitas umum }\end{array}$ \\
\hline 6 & 6 & $\begin{array}{l}\text { Keterjangkauan } \\
\text { harga rumah }\end{array}$ & Moda transportasi & Kesehatan & $\begin{array}{c}\text { Ketersediaan } \\
\text { fasilitas umum }\end{array}$ \\
\hline 7 & 7 & Tipe rumah & Moda transportasi & Keamanan & $\begin{array}{c}\text { Ketersediaan } \\
\text { infrastruktur } \\
\text { rekreasi }\end{array}$ \\
\hline 8 & 8 & $\begin{array}{l}\text { Keterjangkauan } \\
\text { harga rumah }\end{array}$ & $\begin{array}{l}\text { Jarak dengan lokasi } \\
\text { kegiatan/tempat kerja }\end{array}$ & Keamanan & $\begin{array}{l}\text { Ketersediaan } \\
\text { fasilitas umum }\end{array}$ \\
\hline 9 & 9 & Status kepemilikan & $\begin{array}{c}\text { Jarak dengan lokasi } \\
\text { kegiatan/tempat kerja }\end{array}$ & Keamanan & $\begin{array}{l}\text { Ketersediaan } \\
\text { fasilitas umum }\end{array}$ \\
\hline 10 & 10 & $\begin{array}{l}\text { Keterjangkauan } \\
\text { harga rumah }\end{array}$ & Moda transportasi & $\begin{array}{l}\text { Kedekatan } \\
\text { dengan } \\
\text { keluarga }\end{array}$ & $\begin{array}{l}\text { Ketersediaan } \\
\text { fasilitas umum }\end{array}$ \\
\hline 11 & 11 & Tipe rumah & $\begin{array}{c}\text { Jarak dengan lokasi } \\
\text { kegiatan/tempat kerja }\end{array}$ & Kesehatan & $\begin{array}{c}\text { Ketersediaan } \\
\text { infrastruktur } \\
\text { rekreasi }\end{array}$ \\
\hline 12 & 12 & Tipe rumah & $\begin{array}{l}\text { Jarak dengan lokasi } \\
\text { kegiatan/tempat kerja }\end{array}$ & Komunitas & $\begin{array}{c}\text { Ketersediaan } \\
\text { fasilitas umum }\end{array}$ \\
\hline 13 & 13 & $\begin{array}{l}\text { Keterjangkauan } \\
\text { harga rumah }\end{array}$ & Moda transportasi & Keamanan & $\begin{array}{c}\text { Ketersediaan } \\
\text { infrastruktur } \\
\text { rekreasi }\end{array}$ \\
\hline 14 & 14 & Status kepemilikan & $\begin{array}{c}\text { Jarak dengan lokasi } \\
\text { kegiatan/tempat kerja }\end{array}$ & $\begin{array}{l}\text { Kedekatan } \\
\text { dengan } \\
\text { keluarga }\end{array}$ & $\begin{array}{l}\text { Ketersediaan } \\
\text { infrastruktur } \\
\text { rekreasi }\end{array}$ \\
\hline 15 & 15 & $\begin{array}{c}\text { Keterjangkauan } \\
\text { harga rumah }\end{array}$ & $\begin{array}{c}\text { Jarak dengan lokasi } \\
\text { kegiatan/tempat kerja }\end{array}$ & Komunitas & $\begin{array}{l}\text { Ketersediaan } \\
\text { fasilitas umum }\end{array}$ \\
\hline 16 & 16 & Status kepemilikan & Moda transportasi & Komunitas & $\begin{array}{c}\text { Ketersediaan } \\
\text { infrastruktur } \\
\text { rekreasi }\end{array}$ \\
\hline
\end{tabular}




\begin{tabular}{|c|c|c|c|c|c|}
\hline & $\begin{array}{c}\text { Card } \\
\text { ID }\end{array}$ & $\begin{array}{c}\text { Pilihan unit } \\
\text { rumah }\end{array}$ & Aksesibilitas & $\begin{array}{c}\text { Faktor } \\
\text { lingkungan }\end{array}$ & $\begin{array}{c}\text { Pilihan } \\
\text { infrastruktur }\end{array}$ \\
\hline $17^{\mathrm{a}}$ & 17 & $\begin{array}{c}\text { Keterjangkauan } \\
\text { harga rumah }\end{array}$ & Moda transportasi & Keamanan & $\begin{array}{c}\text { Ketersediaan } \\
\text { fasilitas umum }\end{array}$ \\
\hline $18^{\mathrm{a}}$ & 18 & Tipe rumah & $\begin{array}{c}\text { Jarak dengan lokasi } \\
\text { kegiatan/tempat kerja }\end{array}$ & Keamanan & $\begin{array}{c}\text { Ketersediaan } \\
\text { fasilitas umum }\end{array}$ \\
\hline
\end{tabular}

Sumber: Analisis Peneliti, 2017

\section{HASIL DAN PEMBAHASAN}

\section{Perkembangan Guna Lahan Desa Ngijo}

Pada Perkembangan kawasan pinggiran dan perbatasan Kota Malang memperlihatkan adanya pembangunan perumahan dan permukiman baru baik yang dibangun oleh pemerintah, pengembang atau masyarakat. Perubahan fungsi lahan seperti sawah irigasi dan tanah ladang mengindikasi terjadinya invasi lahan. Alih fungsi lahan terbesar di Desa Ngijo terjadi dalam kurun waktu \pm 3 dekade terakhir (Gambar 2.). Rentang tahun 2000-2017 terjadi peningkatan guna lahan peruntukkan permukiman sebesar $70,1 \%$.

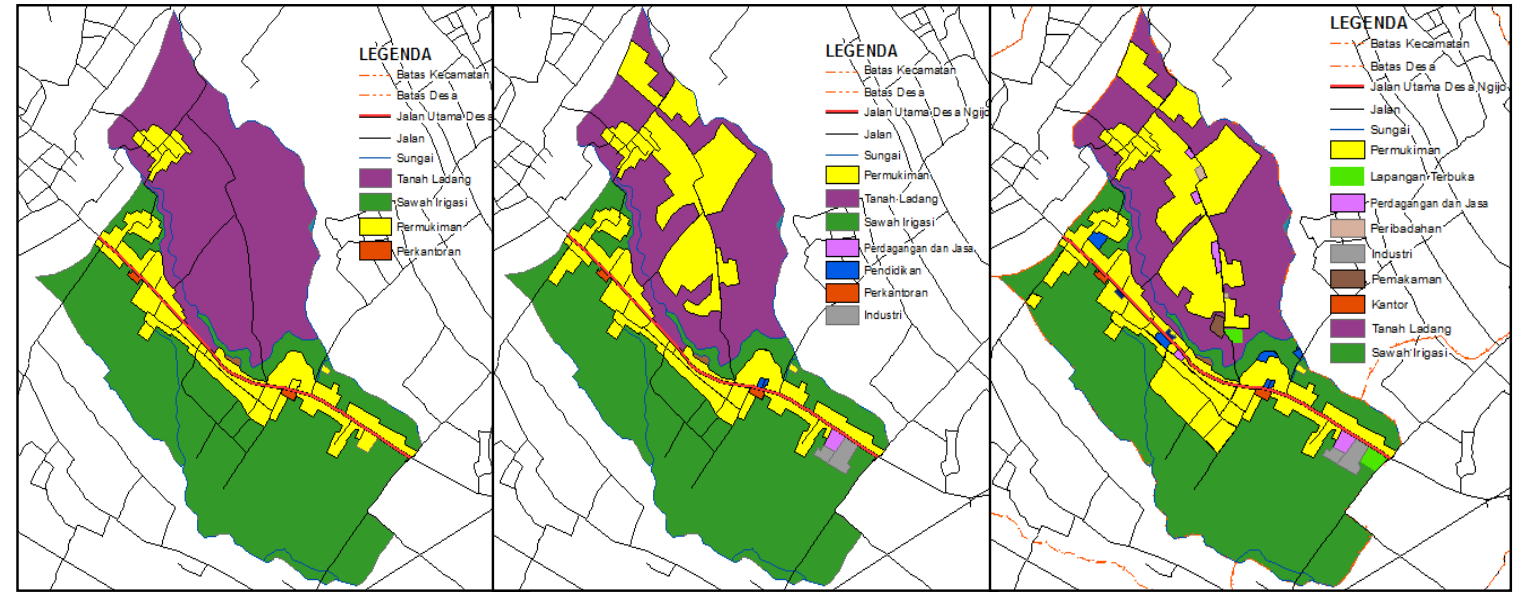

Gambar 2. Peta Perubahan Lahan Desa Ngijo tahun 2000-2017 Sumber: BPN Kabupaten Malang dan Survei Primer, 2017

\section{Penggunaan Lahan Desa Ngijo}

Sebagai kebutuhan pokok, rumah tidak hanya berkisar pada jumlah tempat tinggal yang dihuni dan status pemilikannya, tetapi juga berkaitan dengan luas bangunan, kualitas serta fasilitas penunjang lainnya (Pinem, 2010). Sehingga penggunaan lahan di Desa Ngijo terbagi ke dalam beberapa peruntukan, yang dikelompokkan menjadi pemukiman, pertanian, pendidikan, perdagangan, perkantoran, fasilitas olahraga, industri, pemakaman umum dan lain-lain. Guna lahan di Desa Ngijo tahun 2017 yang diperuntukkan sebagai 
fasilitas umum, seperti pendidikan sebesar 2,38 ha, perdagangan dan jasa sebesar 6,4 ha, perkantoran 7,2 ha, fasilitas olahraga 0,8 ha, industri 4,57 ha dan pemakaman 2,5 ha. Sebagian besar guna lahan Desa Ngijo peruntukkannya didominasi oleh pemukiman dan pertanian yaitu sebesar 43,9\% dan 50,4\%. Luas lahan yang diperuntukkan untuk permukiman adalah sebesar 182,24 ha sedangkan yang diperuntukkan untuk pertanian adalah sebesar 209,33 ha.

Guna lahan untuk permukiman merupakan bentuk nyata dari semakin pesatnya perkembangan permukiman yang ada di Desa Ngijo, tentunya hal tersebut tidak terlepas dari preferensi masyarakat untuk bermukim di kawasan Desa Ngijo. Penggunaan lahan untuk permukiman di Desa Ngijo berkembang secara signifikan, hal tersebut ditandai dengan adanya pembangunan perumahan dan permukiman baru baik yang dibangun oleh pemerintah, pengembang, maupun swadaya masyarakat tiap tahunnya terus meningkat. Lahan menjadi sumber daya langka dan mahal di Kota Malang, Dengan kondisi tersebut mengakibatkan perkembangan kota mengalami pergeseran dari pusat kota ke arah pinggiran dan perbatasan untuk mencari lahan yang luas dan lebih murah.

\section{Preferensi Bermukim Berdasarkan Hasil Analisis Konjoin}

\section{A. Analisis Utilitas (kegunaan) Level Tiap Atribut}

Nilai utilitas level tiap atribut adalah nilai spesifik yang menggambarkan tingkat kepentingan tiap level atribut (sub variabel) dan telah ditentukan sebelumnya. Nilai utilitas level atribut yang diujikan dari analisis konjoin dapat diketahui preferensi responden baik secara individu maupun agregat. Nilai utilitas individu bermanfaat untuk mendesain preferensi masyarakat dalam memilih bermukim di kawasan Desa Ngijo yang bersifat spesifik bagi masing-masing individu. Nilai utilitas agregat menggambarkan nilai kepentingan pilihan yang tersedia secara keseluruhan dari responden penelitian untuk menentukan preferensi bermukim yang paling dominan. Perhitungan agregat dari responden telah dilakukan dengan bantuan program SPSS 22.00 ditampilkan pada Tabel 2.

Tabel 2. Nilai Utilitas Level Atribut/Relatif Penting

\begin{tabular}{c|l|c}
\hline \multicolumn{1}{c|}{ Atribut } & \multicolumn{1}{c|}{ Level atribut } & Utility Estimate \\
\hline \multirow{3}{*}{ Pilihan unit rumah } & 1. Keterjangkauan harga rumah & 0,353 \\
& 2. Status kepemilikan & $-0,177$ \\
& 3. Tipe rumah & $-0,175$ \\
\hline \multirow{2}{*}{ Aksesibilitas } & 1. Ketersediaan moda transportasi & 0,116 \\
& 2. Kedekatan jarak & $-0,116$ \\
\hline
\end{tabular}




\begin{tabular}{l|ll|c}
\hline \multicolumn{1}{c|}{ Atribut } & \multicolumn{1}{|c}{ Level atribut } & Utility Estimate \\
\hline \multirow{4}{*}{ Faktor lingkungan } & 1. Kedekatan dengan keluarga & $-0,132$ \\
& 2. Kesehatan & $-0,103$ \\
& 3. Keamanan & 0,334 \\
& 4. Komunitas & $-0,099$ \\
\hline \multirow{2}{*}{ Pilihan infrastruktur } & 1. Ketersediaan fasilitas umum & 0,128 \\
& 2. Ketersediaan infrastruktur & $-0,128$ \\
\hline Konstanta & & rekreasi & 4,025 \\
\hline
\end{tabular}

Sumber: Hasil Analisis, 2017

\section{- Korelasi Level Atribut Terhadap Atribut Pilihan Unit Rumah}

Keterjangkauan harga rumah merupakan komponen dari unit rumah dan menjadi sebagai salah satu pilihan yang melatarbelakangi masyarakat memilih unit rumah sebagai preferensi bermukim. Nilai berdasarkan hasil perhitungan konjoin menyatakan bahwa keterjangkauan harga rumah merupakan komponen dari unit rumah yang memiliki nilai tertinggi diartikan bahwa sebagian besar responden menyatakan keterjangkauan harga rumah merupakan alasan terpenting dalam memutuskan untuk bermukim di kawasan Desa Ngijo. Pada dasarnya dalam pengambilan keputusan yang berhubungan dengan permukiman masyarakat akan selalu melakukan perbandingan harga atau biaya yang dibutuhkan dalam proses bermukim(Reksohadiprodjo, 2001). Harga rumah menjadi pilihan terpenting dengan pertimbangan kemampuan masyarakat untuk memiliki rumah (daya beli) dalam penentuan preferensi bermukimnya. Dengan kondisi harga rumah yang tergolong rendah, daya beli masyarakat akan semakin tinggi.

\section{- Korelasi Level Atribut Terhadap Atribut Aksesibilitas}

Berdasarkan hasil analisis, level atribut berupa ketersediaan moda transportasi merupakan pilihan yang dianggap penting dalam atribut aksesibilitas dengan hasil nilai positif. Responden beranggapan bahwa tersedianya moda transportasi akan jauh lebih penting jika melihat pertimbangan dengan jarak lokasi kegiatan dalam penentuan preferensi bermukim. Hal tersebut terjadi karena dengan tersedianya moda transportasi yang memadai, maka aktivitas untuk mencapai suatu lokasi kegiatan akan menjadi lebih mudah. Pada umumnya, responden di Desa Ngijo memiliki kendaraan pribadi untuk mendukung mobilitas harian. Terkait hal tersebut, moda transportasi umum yang tersedia di kawasan Desa Ngijo cukup terbatas, sehingga responden lebih memilih menggunakan moda transportasi pribadi dan beranggapan menggunakan moda transportasi pribadi akan lebih mudah dan mengefektifkan waktu, tentunya tanpa harus 
meunggu transportasi umum. Terkait dengan aksesibilitas, yaitu menggunakan moda transportasi pribadi berupa mobil atau sepeda motor mempunyai aksesibilitas yang lebih baik daripada angkutan umum atau dengan berjalan kaki (Tamin, 2000).

\section{- Korelasi Level Atribut Terhadap Atribut Faktor Lingkungan}

Level atribut keamanan merupakan level atribut faktor lingkungan yang dianggap paling penting dari prefrensi bermukim masyarakat kawasan Desa Ngijo, yaitu dengan nilai hasil analisis sebesar $+0,334$. Keamanan merupakan komponen dari faktor lingkungan yang menjadi salah satu pertimbangan dari preferensi bermukim. Berdasarkan hasil analisis konjoin, keamanan menjadi salah satu pertimbangan penting dalam preferensi bermukim, karena responden beranggapan bahwa lingkungan perukiman yang aman (dari bencana alam, kriminalitas, dan lain-lain) merupakan hal terpenting dalam menunjang proses bermukim di Desa Ngijo. Lingkungan yang aman membuat masyarakat merasa nyaman tanpa perlu merasa cemas dengan kondisi lingkungan sekitar permukiman.

\section{- Korelasi Level Atribut Terhadap Atribut Pilihan Infrastruktur}

Ketersediaan infrastruktur umum merupakan level atribut yang dianggap paling penting apabila dibandingkan dengan tersedianya pilihan infrastruktur rekreasi. Terkait kondisi di Desa Ngijo, teridentifikasi preferensi masyarakat sehingga memilih bermukim di kawasan tersebut dengan tersedianya infrastruktur utama seperti fasilitas pendidikan, perbelanjaan, kesehatan, dan lain-lain. Tentunya hal tersebutmerupakansaranapermukiman dengan tingkat kebutuhan yang dianggapsangatpenting untukmenunjang aktivitasseharihari. Pilihan yang ada berupa ketersediaan fasilitas umum seperti fasilitas perbelanjaan, pendidikan, dan kesehatan merupakan unsur penting yang harus ada di kawasan permukiman(Prillwitzetc all, 2007). Responden penelitian beranggapan bahwa fasilitas umum di kawasan Desa Ngijo tergolong lengkap untuk memenuhi kebutuhan hidup seharihai, namun jika status kelengkapan tersebut coba dibandingkandengan fasilitas umum yang berada pusatkota, maka tentunya di Desa Ngijo masih tergolong rendah.

\section{B. Analisis Tingkat Kepentingan Atribut}

Analisis konjoin sangat bermanfaat untuk mengetahui faktor mana yang paling dipertimbangkan oleh responden ketika mengevaluasi beberapa atribut sekaligus. Dengan mengetahui tingkat kepentingan relatif, maka peneliti dapat mendesain preferensi yang sesuai dengan kombinasi atribut dan dianggap penting oleh responden. Dengan menggunakan SPSS 22.00 diperoleh hasil preferensi bermukim masyarakat Desa Ngijo berdasarkan pilihan responden dapat dilihat pada Tabel 3. 
Tabel 3. Tingkat Kepentingan Atribut Pilihan Bermukim

\begin{tabular}{c|c}
\hline Atribut & Importance Values \\
\hline Pilihan unit rumah & $38,3 \%$ \\
\hline Aksesibilitas & $14,3 \%$ \\
\hline Faktor lingkungan & $35,9 \%$ \\
\hline Pilihan infrastruktur & $11,5 \%$ \\
\hline Total & $100 \%$ \\
\hline
\end{tabular}

Sumber: Hasil Analisis, 2017

Unit rumah sebagai pilihan paling penting tidak lepas dari level atribut yang tersedia, yaitu keterjangkauan harga rumah, status kepemilikan, dan tipe rumah. Dikaitkan dengan hasil utilitas level atribut yang tertinggi yang berupa keterjangkauan harga rumah, maka masyarakat tentu memiliki kecenderungan lebih untuk memilih bermukim di kawasan perbatasan, tentunya dengan pertimbangan mengenai harga unit rumah yang dinilai cukup murah. Kondisi tersebut diakibatkan oleh harga lahan dan harga rumah di pusat kota yang sangat tinggi, sehingga masyarakat memilih untuk bermukim ke arah perbatasan dengan asumsi kemampuan kepemilikan rumah akan semakin besar. Hal tersebut sejalan dengan keberadaan status kepemilikan dan tipe rumah, yaitu semakin tinggi daya beli masyarakat, maka status kepemilikan tentu akan dapat diperjelas sehingga masyarakat dapat memilih tipe rumah yang sesuai keinginan dan kemampuan membeli. Hal-hal tersebut dianggap sebagai faktor yang melandasi atribut unit rumah menjadi pilihan paling penting pada preferensi bermukim masyarakat di Desa Ngijo.

Faktor lingkungan memiliki posisi kedua dalam hasil analisis tingkat kepentingan atribut preferensi bermukim, yaitu dengan persentase sebesar 35,9\%. Hal ini terkait dengan tingkat kenyamanan masyarakat dalam bermukim di suatu kawasan. Masyarakat menginginkan lingkungan permukiman yang nyaman dan aman. Berdasarakan catatan kejadian yang dijelaskan di dalam Profil Desa Ngijo Tahun 2017, lingkungan permukiman di Desa Ngijo cukup tergolong aman, terkait status kriminalitas dan bencana yang dapat terjadi kapan saja telah dinilai tidak sampai pada titik kronis yang membahayakan masyarakat. Dalam hal ini masyarakat beranggapan dengan kondisi tersebut akan merasa tenang bermukim di kawasan Desa Ngijo.

Selanjutnya tingkat kepentingan atribut preferensi bermukim pada posisi ketiga adalah aksesibilitas dengan persentase sebesar 14,3\%. Tingkat kepentingan atribut aksesibilitas masih tergolong rendah, hal tersebut dikarenakan moda transportasi umum di kawasan Desa Ngijo yang melayani persil-persil permukiman cukup terbatas. Dalam hal ini moda transportasi umum yang tersedia hanya berupa ojek motor, sehingga masyarakat 
secara umum menganggap bahwa memiliki kendaraan pribadi menjadi suatu keharusan untuk menunjang mobilitas harian. Terkait dengan level atribut aksesibilitas berupa jarak dengan lokasi kegiatan juga menjadi pertimbangan besar, dikarenakan rata-rata masyarakatnya bekerja di luar kawasan Desa Ngijo sehingga membutuhkan sedikit waktu lebih untuk mencapai lokasi kegiatan (tempat bekerja) dan membutuhkan moda transportasi sebagai penunjang utama mencapai lokasi tujuan. Hal tersebut yang menyababkan secara umum masyarakat tidak memilih atribut aksesibilitas sebagai prioritas preferensi bermukim.

Tingkat kepentingan atribut yang paling rendah berdasarkan hasil analisis adalah atribut pilihan infrastruktur yaitu dengan persentase sebesar 11,5\%. Hal tersebut dikarenakan sarana dan prasarana yang tersedia di lingkungan permukiman Desa Ngijo tergolong rendah apabila dibandingkan dengan pusat kota. Rata-rata masyarakat Desa Ngijo bekerja di luar kawasan Desa Ngijo termasuk di pusat Kota Malang dan memilih bermukim di kawasan perbatasan dikarenakan harga lahan dan harga rumah di pusat kota tergolong tinggi. Dalam hal ini dapat diartikan bahwa rata-rata masyarakat di Desa Ngijo merupakan pendatang, sehingga cenderung melakukan perbandingan kelengkapan fasilitas yang tersedia dengan pusat kota. Hal tersebut dianggap sebagai faktor atribut pilihan infrastruktur merupakan pilihan dengan tingkatan yang paling rendah apabila dibandingkan dengan atribut preferensi bermukim lainnya.

\section{Uji Signifikansi dan Pengukuran Predictive Accurancy}

Nilai dari Pearson's $R$ adalah 0,924 (92,4\%) dan nilai dari Kendall's Tau adalah $0,800(80 \%)$ dan memiliki nilai p-value (signifikansi) masing-masing lebih kecil dari $\alpha=$ 0,05 (derajat signifikansi) (Tabel 4.). Nilai yang dihasilkan dari analisis konjoin membuktikan bahwa adanya hubungan yang cukup kuat atau terdapat ketepatan dalam memprediksi yang mengindikasi model atau mengindikasi pilihan bermukim yang dibuat sudah cukup baik. Nilai dari Pearson's $R$ sebesar 0,924 dan nilai dari Kendall's Tau sebesar 0,800 meunjukkan kemampuan memprediksi yang bagus (good predictive ability), artinya data hasil perhitungan dari kombinasi yang dibentuk berkorelasi sangat kuat dengan data yang diperoleh berdasarkan pendapat responden. Dapat disimpulkan bahwa pilihan unit rumah, aksesibilitas, faktor lingkungan, dan pilihan infrastruktur merupakan atribut-atribut yang secara signifikan dipertimbangkan oleh masyarakat dalam preferensi bermukim di Desa Ngijo. 
Tabel 4. Korelasi antara Variabel Observed dan Estimated Preferences

\begin{tabular}{l|c|c}
\hline Keandalan dan Kesahihan & Nilai & \multicolumn{1}{c}{ Sig. } \\
\hline Pearson's R & 0,924 & 0,000 \\
\hline Kendall's tau & 0,800 & 0,000 \\
\hline \multicolumn{2}{c}{ Sumber: Hasil Analisis, 2017}
\end{tabular}

\section{KESIMPULAN DAN SARAN}

\section{Kesimpulan}

Berdasarkan proses analisis yang telah dilakukan pada bab hasil dan pembahasan sebelumnya, maka kesimpulan dari penelitian "Preferensi Bermukim Masyarakat Perbatasan Kota dan Kabupaten Malang (Studi Kasus Desa Ngijo Kec.Karangploso)" berupa faktor-faktor yang menjadi pertimbangan responden dalam menentukan preferensi bermukim di Desa Ngijo adalah:

a. Atribut 1 (pilihan unit rumah) pada level 1 (keterjangkauan harga rumah), yaitu harga rumah menjadi pertimbangan yang paling penting, dengan kondisiharga lahan maupun rumah dikawasanperbatasan kota tergolong murah apabiladibandingkan dengan harga dipusat kota.

b. Atribut 2 (aksesibilitas) pada level1 (ketersediaan moda transportasi), yaitu masyarakat beranggapan dengan tersedianya moda transportasi yang memadai, maka aktivitas untuk mencapai suatu lokasi kegiatan akan menjadi lebih mudah.

c. Atribut 3 (faktor lingkungan) pada level3 (keamanan), yaitu kondisi lingkungan permukiman yang aman membuat masyarakat merasa nyaman tanpa perlu merasa cemas dengan kondisi lingkungan sekitar.

d. Atribut 4 (pilihan infrastruktur) pada level1 (ketersediaan fasilitas umum), yaitu masyarakat beranggapan fasilitias umum merupakan kebutuhan primer, merupakan sarana permukiman dengan tingkat kebutuhan yang dianggap sangat penting untuk menunjang aktivitas sehari-hari.

Pada analisis tingkat kepentingan diperoleh bahwa urutan nilai kepentingan pada masing-masing atribut/variabel adalah pilihan unit rumah dengan nilai kepentingan 38,3\%, faktor lingkungan dengan nilai kepentingan 35,9\%, aksesibilitas dengan nilai kepentingan $14,3 \%$ dan yang terakhir pilihan infrastruktur dengan nilai kepentingan $11,5 \%$. Pilihan unit rumah menjadi pilihan yang paling dominan tidak lepas dari level atribut yang tersedia, yaitu keterjangkauan harga rumah, status kepemilikan, dan tipe rumah, yaitu dengan kondisi rumah yang murah semakin tinggi daya beli masyarakat, maka status kepemilikan 
tentu akan dapat diperjelas sehingga masyarakat dapat memilih tipe rumah yang sesuai keinginan dan kemampuan membeli. Sedangkan pilihan infrastruktur menjadi faktor pilihan bermukim yang paling rendah dikarenakan sarana dan prasarana yang tersedia di lingkungan permukiman Desa Ngijo tergolong rendah apabila dibandingkan dengan pusat kota.

\section{Saran}

Kebijakan yang diarahkan untuk mengurangi dampak negatif dari urban sprawl terkait adanya hasil preferensi bermukim masyarakat kawasan perbatasan, yaitu pengendalian lokasi perumahan yang dibangun oleh pihak pengembang, pengembangan pusat-pusat pertumbuhan baru, serta rencana untuk melengkapi infrastruktur lingkungan permukiman. Apabila dikaji secara makro, perkembangan permukiman secara umum di Kecamatan Karangploso secara khusus di Desa Ngijo cukup menguntungkan sebagai upaya pemenuhan kebutuhan rumah yang tidak dapat lagi terfasilitasi oleh pusat kota.

\section{DAFTAR PUSTAKA}

Ekartaji, P., Yunus, H., S., \& Rahardjo, N. (2014). Kajian Kualitas Lingkungan Permukiman di Daerah Pinggiran Kota Kasus di Desa Ngestiharjo. Majalah Geografi Indonesia. 28 (1), 96-102.

Hasan, Iqbal. (2004). Analisis Data Penelitian Dengan Statistik . Jakarta: Bumi Aksara.

Jansen, S.J.T., Henny C.C.H.C., \& Roland W.G. (2011). The Measurement and Analysis of Housing Preference and Choice. Sprringer: New York.

Oktaviani, Resti., \& Soteomo, Sugiono. (2016). Pengaruh Keberadaan Kawasan Kota Baru Lippo Karawaci Terhadap Perkembangan Fisik, Ekonomi, dan Sosial Pada Kawasan di Sekitarnya. Jurnal Ruang. 1 (1), 1-10.

Pinem, Mbina. (2010). Pengaruh Sosial Ekonomi Terhadap Kualitas Permukiman di Kelurahan Sidorejo Kecamatan Medan Tembung Kota Meda. Jurnal Geografi. 2 (2), $71-80$.

Prillwitz, J., Harms, S., \& Lanzendorf, M. (2007). Interactions between residential relocations, life course events, and daily commute distances. Transportation Research Record. 21 (1), 64-69.

Reksohadiprodjo, Sukanto. (2001). Ekonomi Perkotaan. Yogyakarta:BPFE Yogyakarta. 
Jurnal Planologi Vol. 15, No. 2, Oktober 2018

Available : http://jurnal.unissula.ac.id/index.php/psa

Rupini, A.A.A.D., Dewi, N.K.A., \& Sueca, N.K. (2017). Implikasi Alih Fungsi Lahan Pertanian Pada Perkembangan Spasial Daerah Pinggiran Kota. Undagi Jurnal Ilmiah Arsitektur. 5 (2), 9-18.

Sadana, Agus S. (2014). Perencanaan Kawasan Permukiman. Jakarta: Graha Ilmu.

Sinulingga, B.D. (2005). Pembangunan Kota Tinjauan Regional dan Lokal. Jakarta: Pustaka Sinar Harapan

Sugiyono. (2011). Metode Penlitian Kuantitatif Kualitatif dan $R \& D$. Bandung: Alfabeta.

Supranto, Johanes. (2010). Analisis Multivariat Arti dan Interpretasi. Jakarta: Rineka Cipta.

Tamin, Ofyar Z. (2000). Perencanaan dan Pemodelan Transportasi. Bandung: Institut Teknologi Bandung. 